\title{
Timing of Cut-Stump Herbicide Applications for Killing Hardwood Trees on Power Line Rights-of-Way
}

\author{
Benjamin D. Ballard and Christopher A. Nowak
}

\begin{abstract}
Removal of tall-growing trees on power line rights-of-way is necessary for the safe and reliable transmission of electricity. Cut-stump herbicide treatments have been used at different times of the year to control resprouting and suckering of unwanted hardwood trees on power line corridors in the northeastern United States with varying degrees of success. Growing season applications have typically been thought to be most effective; however, if a high percentage of mortality could also be achieved by selecting an appropriate herbicide mix for early-spring and late-fall applications, vegetation managers would have more flexibility in prescribing and scheduling treatments. The authors evaluated mortality and amount of herbicide applied for April, June, and November using operational-style cut-stump treatments with three herbicide mixes-Accord ${ }^{\circledR}+$ Arsenal $^{\circledR}$, Garlon $4{ }^{\circledR}+$ Stalker $^{\circledR}$, and Pathway ${ }^{\circledR}$. After 2 years, over $90 \%$ mortality was achieved for at least one herbicide mix at all three application dates. Mortality varied by both mix and application date, consistent with herbicide mode of action. In April and June, Accord + Arsenal had lower mortality than Garlon $4+$ Stalker or Pathway, but in November, it resulted in slightly higher mortality than the other two mixes. The Garlon $4+$ Stalker mix and Pathway had equally high mortality for all treatment dates. Successful use of the cut-stump method in spring through fall may be contingent upon matching herbicide mix to the date of application. These results indicate that Garlon $4+$ Stalker or Pathway could be used April through November, but applications with Accord + Arsenal should be made in late summer or fall. These recommendations should be evaluated in other regions and with additional target tree species. The quantity of herbicide used by operational crews varied among application dates and herbicide mixtures and appeared to be strongly influenced by spray equipment and the person applying the herbicide. Minor refinements in application techniques and equipment have the potential to reduce the amount of herbicide used without adversely affecting efficacy, and warrant further consideration.
\end{abstract}

Key Words. Cut surface; electric transmission lines; glyphosate; herbicide use rates; imazapyr; picloram; triclopyr; 2,4-D; vegetation management.

Electric transmission line rights-of-way are important technological and ecological features of the landscape. The primary purpose of these rights-of-way is to provide for the safe, reliable transmission of electricity. Active vegetation management helps ensure that this purpose is met by controlling populations of tall-growing trees that can act as conduits for electricity and cause ground-fault disruptions in transmission. Using an Integrated Vegetation Management approach on rights-of-way to control tall-growing trees requires a broad suite of vegetation management treatments, including chemical, physical and mechanical, and biological and ecological methods (McLoughlin 1997, 2002). Herbicides are important vegetation management tools for controlling hardwood trees that would otherwise resprout or sucker when using an alternative method such as handcutting or mowing. Commonly used herbicide application methods include foliar, stemfoliar, basal, and cut-stump treatments (Gangstad 1989; Nowak et al. 1992, 1993; Abrahamson et al. 1995; Sulak and Kielbaso 2000). Cut-stump is an important method because it can be selectively applied with narrow zones of off-target herbicide deposition and minimal disturbance to desirable, nontarget plants (Nowak and Ballard 2005). Unlike many foliar and basal treatments, cut-stump treatments also have low visual impacts (e.g., no brown-out or standing dead trees). Cut-stump treatments may be particularly useful in areas where off-target impact must be minimized, such as wetlands and riparian buffers.

The cut-stump treatment combines the use of mechanical and chemical methods. The mechanical component is typically done using a chain saw or brush saw to cut a stem near groundline. The herbicide application is typically made immediately, or soon after cutting within a specified period per label instructions. Depending on the herbicide mixture, the application is made either directly to the cambium, or to the cambium plus the bark, and any exposed roots.

In the northeastern United States, cut-stump treatments have been applied operationally at different times of the year to control hardwood trees on power line rights-of-way with varying degrees of success (K. Finch, retired, Niagara Mohawk, a National Grid Co., pers. comm.). Operational use of the cut-stump method was thought to yield best results when applied during the growing season, but it has been applied with some success at other times of the year. Cut-stump treatments have been used for crop-tree release in forestry in the dormant and growing season, with some products working better in the dormant season (Zedaker et al. 1987). Cut-stump 
treatments have also been used in forestry for precommercial thinnings during the dormant season (Troth et al. 1986). In contrast to forestry applications, power line right-of-way treatments require very high mortality due to the potential impacts that surviving trees could have on the safe and reliable transmission of electricity. Although utility foresters will likely have their own acceptable level of mortality, having over $90 \%$ mortality for cut-stump treatments is often considered effective for right-of-way vegetation management (K. Finch, pers. comm.).

Use of different herbicides, alone or in mixtures, may allow for greater flexibility in tailoring treatments to specific site and vegetation conditions and time of the year. Because many tree species are typically encountered during operational vegetation management of rights-of-way, herbicide mixtures may provide a wider spectrum of control, killing more species than a single-herbicide treatment. For example, if one of the herbicides in the mix is not very effective on a particular species, the other herbicide(s) may be. There has been little research evaluating date of cut-stump application using mixtures of herbicides. Knowing which herbicide mixes work best as a cut-stump treatment early in the spring and late in the fall would give more flexibility to vegetation managers in prescribing and scheduling treatments.

The primary objective of our study was to determine what herbicide mixes could be operationally applied using the cutstump treatment method at different times of the year to efficaciously control common hardwood tree species in the Northeast. We evaluated efficacy, measured as percentage of mortality, of April, June, and November operational-style applications of cut-stump treatments with three herbicide mixes: Accord ${ }^{\circledR}$ (glyphosate) + Arsenal ${ }^{\circledR}$ (imazapyr), Garlon $4{ }^{\circledR}$ (triclopyr) + Stalker ${ }^{\circledR}$ (imazapyr), and Pathway ${ }^{\circledR}$ (2,4-D and picloram). We expected that greater than $90 \%$ mortality could be achieved at each date of application but hypothesized that some herbicides would be more efficacious than others at different times of the year because of differences in their mode of action. A secondary objective was to quantify the amount of herbicide applied by the operational crews to ensure that typical amounts of herbicide had been used to kill right-of-way trees. We expected that the amount of herbicide used would be comparable among treatments.

\section{MATERIALS AND METHODS}

\section{Study Area Description}

The study was conducted from spring 2000 through late summer 2002 on the Volney-Marcy power line corridor in the towns of Lee, Western, and Floyd in Oneida County, New York, U.S. $\left(43^{\circ} 21^{\prime} \mathrm{N}, 75^{\circ} 32^{\prime} \mathrm{W}\right.$ to $\left.43^{\circ} 15^{\prime} \mathrm{N}, 75^{\circ} 17^{\prime} \mathrm{W}\right)$. The Volney-Marcy corridor is a $70 \mathrm{~m}(230 \mathrm{ft})$ wide, $765 \mathrm{kV}$ transmission line right-of-way constructed in 1982 to 1983. The right-of-way passes through the Interlobal Highland Re- gion, between the Tug Hill Plateau and the Mohawk Valley. It is surrounded by northern hardwood forest with a predominance of red maple (Acer rubrum) and eastern hemlock (Tsuga canadensis) and a mixture of both abandoned and active agricultural land, resulting in a population of common shade-intolerant, early-successional tree species. Three study blocks were located approximately 6 to $18 \mathrm{~km}$ (3.6 to 10.8 mi) apart across a $24 \mathrm{~km}(14.4 \mathrm{mi})$ length of the right-of-way.

\section{Experimental Design}

Three treatment dates and three herbicide mixes were evaluated using a $3 \times 3$ factorial experiment in a randomized complete block design. The three blocks were designed to account for variability associated with people (applicators), time of application within a day, and tree size and density (vegetation conditions) among plots. Herbicide mix and date of application effects were tested for percentage mortality and amount of herbicide associated with cut-stump treatment of common right-of-way trees. Gray birch (Betula populifolia) was the dominant target species $(41 \%)$, followed by pin cherry (Prunus pensylvanica, 18\%), black cherry (Prunus serotina, 17\%), red maple (A. rubrum, 14\%), and quaking aspen (Populus tremuloides, $7 \%$ ). Average stump diameter was $8.5 \mathrm{~cm}$ (3.4 in) across all treatment plots, ranging from 5.6 to $11.7 \mathrm{~cm}$ (2.24 to 4.68 in). Herbicide mixes used were Accord + Arsenal, Garlon $4+$ Stalker, and Pathway (Table 1). Treatment dates for all three herbicide mixes were 19 April, 26-27 June, and 28 November. The 27 treatment plots (nine per block) averaged 0.04 ha $(0.10 \mathrm{ac})$ in size, ranging from 0.02 to 0.11 ha $(0.05$ to $0.28 \mathrm{ac}$ ). Results were based upon individual tree measurements and are reported as percentage mortality and amount of herbicide used on per-acre or pertree basis, and thus not sensitive to plot size.

\section{Treatments}

Treatments were applied using operational spray crews on contract with Niagara Mohawk, a National Grid Company (formerly Niagara Mohawk Power Corp.). Two-person crews applied the treatments-one person felled trees with a chain saw, and the other followed, immediately spraying herbicide. Accord + Arsenal and Pathway treatments were applied using a hand-pump spray bottle [Tolco pump-up spray applicator, $\sim 2 \mathrm{~L}(2.12 \mathrm{qt})]$ in April and June and a generic trigger spray bottle $[\sim 500 \mathrm{~mL}(17 \mathrm{fl} \mathrm{oz})$; different crew] in November. Garlon $4+$ Stalker treatment applications at all treatment dates were made using Birchmeyer hand-operated backpack sprayers equipped with a basal wand, consistent with the application methods for this mixture (Table 1).

\section{Data Collection}

Before treatment, ten trees were chosen across each plot at random. The trees were stratified across the range of tree sizes and species. Each combination of herbicide mix and 
Table 1. Herbicide treatment mixtures and quantity of herbicide mix applied.

\begin{tabular}{|c|c|c|c|c|c|c|}
\hline Herbicide treatment & Herbicide mix & $\mathrm{K}_{\mathrm{ow}}^{\mathrm{z}}$ & $\begin{array}{l}\text { Target zone for } \\
\text { application }\end{array}$ & $\begin{array}{l}\text { Quantity } \\
\text { applied }\end{array}$ & $\begin{array}{l}\text { Tree density } \\
\text { treated }\end{array}$ & $\begin{array}{l}\text { Average tree } \\
\text { diameter }\end{array}$ \\
\hline Accord + Arsenal & $\begin{array}{l}40 \% \text { Accord }(16.6 \% \\
\text { a.i. glyphosate) and } \\
2 \% \text { Arsenal }(0.6 \% \\
\text { a.i. imazapyr) mixed } \\
\text { with water }\end{array}$ & $\begin{array}{l}\text { Glyphosate: } \\
0.0006-0.0017 \\
\text { Imazapyr: } \\
1.3\end{array}$ & Cambium area & $\begin{array}{l}10.2 \mathrm{~L} / \mathrm{ha} \\
(4.4 \mathrm{qt} / \mathrm{ac})\end{array}$ & $\begin{array}{l}1,620 \text { stems/ha } \\
\quad(660 \text { stems/ac })\end{array}$ & $\begin{array}{l}8.1 \mathrm{~cm} \\
\quad(3.24 \mathrm{in})\end{array}$ \\
\hline Garlon $4+$ Stalker & $\begin{array}{l}20 \% \text { Garlon } 4(12.3 \% \\
\text { a.i. triclopyr) and } \\
1 \% \text { Stalker }(0.3 \% \\
\text { a.i. imazapyr) mixed } \\
\text { with Hy-grade EC } \\
\text { basal oil }\end{array}$ & $\begin{array}{l}\text { Triclopyr: } \\
0.11-2.64 \\
\text { Imazapyr: } \\
1.3\end{array}$ & $\begin{array}{l}\text { Cut surface, plus bark } \\
\text { of stump and exposed } \\
\text { root collar and roots, } \\
\text { to the point of runoff }\end{array}$ & $\begin{array}{l}17.4 \mathrm{~L} / \mathrm{ha} \\
\quad(7.4 \mathrm{qt} / \mathrm{ac})\end{array}$ & $\begin{array}{l}\text { 1,610 stems/ha } \\
\quad(650 \text { stems/ac })\end{array}$ & $\begin{array}{l}8.7 \mathrm{~cm} \\
\quad(3.48 \mathrm{in})\end{array}$ \\
\hline Pathway & $\begin{array}{l}\text { A "ready-to-use" } \\
\text { herbicide }(20.9 \% \\
\text { a.i. } 2,4-\mathrm{D} \text { and } 5.4 \% \\
\text { a.i. picloram) }\end{array}$ & $\begin{array}{l}\text { 2,4-D: } 2.81^{\mathbf{y}} \\
\text { Picloram: } \\
\text { 1.4-83.2 }\end{array}$ & Cambium area & $\begin{array}{l}10.4 \mathrm{~L} / \mathrm{ha} \\
\quad(4.4 \mathrm{qt} / \mathrm{ac})\end{array}$ & $\begin{array}{l}\text { 1,650 stems/ha } \\
\quad(670 \text { stems/ac })\end{array}$ & $\begin{array}{l}8.6 \mathrm{~cm} \\
\quad(3.44 \mathrm{in})\end{array}$ \\
\hline
\end{tabular}

${ }^{\mathrm{z}}$ Ahrens (1994).

${ }^{\mathrm{y}}$ U.S. EPA (1998).

application date was represented by 28 to 30 trees with 10 trees from each of three blocks, except a few that could not be found the second year. After treatment, all treated trees in the plots were counted to determine tree density, and sample trees were located. We then measured the diameter of the cut surface of each sample tree. Two diameters were measured for each tree and averaged. At the end of the first (2001) and second (2002) growing season, each sample tree was examined to determine mortality or survival based on green cambium or foliage. Because we observed changes in individual tree status between 1 and 2 years after treatment, with some trees perceived to be dead 1 year after treatment but alive the second year, and vice versa, we report only second-year mortality.

The amount of herbicide applied in each plot was determined by weighing spray bottles before and after treatment to ensure that normal, adequate amounts of herbicide were applied. Volumes for the April and June treatments were calculated using specific gravities of each herbicide mix, derived from manufacturer's Materials Safety Data Sheets. November treatments were measured volumetrically in the field. The quantity of herbicide applied was calculated on per-area and per-tree bases.

\section{Statistical Methods}

Analysis of variance (ANOVA) with a $3 \times 3$ factorial experiment in a randomized complete block design (plot as the experimental unit, $n=27$ ) was used to test for herbicide mix and application date effects on percentage mortality and amount of herbicide used. The SAS program (SAS Institute 2002) was used to conduct all statistical analyses. An $\alpha$-level of 0.10 was used as the critical value to determine statistical significance, though $P$ values up to 0.20 were considered as indicating potentially meaningful results. If a significant interaction was observed $(\alpha \leq 0.15)$ between herbicide mix and date of application, we tested simple effects. ANOVA was also used to verify that treatment plots had comparable densities of treated trees.

Since there was a marginally significant difference in tree density by date of application $(P=0.19)$ but not for herbicide mix $(P=0.99)$, and the amount of herbicide applied per hectare was strongly correlated with the number of trees treated ( $r=0.60, P<0.01, n=27)$, we report results for herbicide use calculated on a per-tree basis. These results were comparable to ANOVA with herbicide use on a perhectare basis.

Pearson product-moment correlations were calculated between the amount of herbicide applied per hectare and the number of trees treated, between percentage mortality and average stump diameter, between percentage mortality and herbicide applied per tree, and between stump diameter and amount of herbicide applied per tree. We were initially concerned that tree size could have an influence on the efficacy of the treatments. However, because correlation between stump diameter and percentage mortality was low $(r=0.25$, $P=0.20, n=27$ ), we used ANOVA rather than analysis of covariance.

\section{RESULTS}

\section{Percentage Mortality}

Mortality of cut-stump-treated trees was affected by both herbicide mix and application date (Figure 1). Differences in percentage mortality among herbicide mixes were significant but differed by treatment date (significant herbicide mix by 


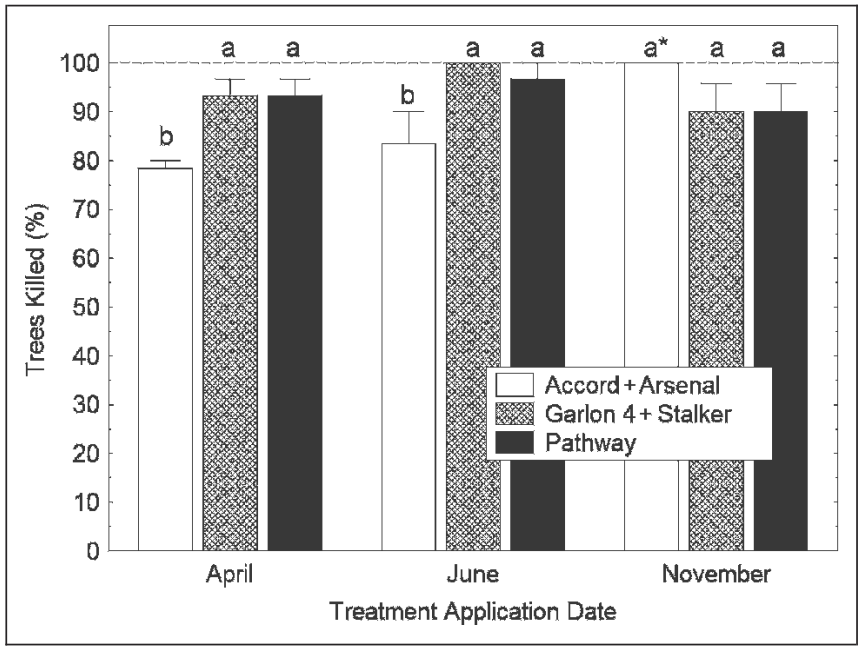

Figure 1. Percentage mortality for three cut-stump herbicide treatments (Accord + Arsenal, Garlon 4 + Stalker, and Pathway) applied at three times of the year (19 April, 26-27 June, and 28 November 2000). Error bars represent one standard error of the mean. Bars with different letters denote significant differences $(\alpha=0.10)$ among herbicide mixes for a given date and among dates for a given herbicide mix. ${ }^{*}$ Differences between Accord + Arsenal versus Garlon 4 + Stalker or Pathway in November were marginally significant $(P=0.12)$.

application date interaction, Table 2). In April and June, both the Garlon $4+$ Stalker and Pathway treatments resulted in higher mortality than Accord + Arsenal (Figure 1). All herbicide mixtures resulted in high mortality in November, with

Table 2. $P$ values for the overall ANOVA, simple effects of herbicide mix within dates of application, and simple effects of dates of application within herbicide mix on percentage mortality and quantity of herbicide applied per tree.

\begin{tabular}{lclc}
\hline & & $\begin{array}{l}\text { \% mortality } \\
(P \text { values })\end{array}$ & $\begin{array}{l}\text { Herbicide } \\
\text { per tree } \\
(P \text { values })\end{array}$ \\
Sources of variation & $d f$ & 0.95 & 0.05 \\
Block & 2 & 0.12 & $<0.01$ \\
Herbicide mix & 2 & 0.28 & $<0.01$ \\
Date & 2 & $\mathbf{0 . 0 2}$ & $<\mathbf{0 . 0 1}$ \\
Herbicide mix $\times$ date & 4 & & \\
Error & 16 & &
\end{tabular}

Simple effects of herbicide mix within:

\begin{tabular}{lrrr}
\hline April & 2 & $\mathbf{0 . 0 4}$ & $<\mathbf{0 . 0 1}$ \\
June & 2 & $\mathbf{0 . 0 3}$ & 0.36 \\
November & 2 & 0.19 & 0.89 \\
Simple effects of date within: & & & \\
\hline Accord + Arsenal & 2 & $\mathbf{0 . 0 1}$ & $\mathbf{0 . 0 7}$ \\
Garlon 4 + Stalker & 2 & 0.27 & $<\mathbf{0 . 0 1}$ \\
Pathway & 2 & 0.56 & 0.39 \\
\hline
\end{tabular}

Accord + Arsenal slightly higher at $100 \%$ (Figure 1; $P=$ 0.12 ).

Percentage mortality also differed among treatment dates, but rankings varied by herbicide mix (Figure 1). Percentage mortality associated with the Accord + Arsenal treatment was highest in November compared to April and June. There was no meaningful difference in tree mortality among dates for the Garlon $4+$ Stalker or Pathway treatments, with mortality over $90 \%$ for all dates.

\section{Herbicide Use}

The amount of herbicide applied differed among herbicide mixes, but those differences varied by treatment date (Table 2 and Figure 2). In April, the Garlon $4+$ Stalker treatment had more herbicide applied per tree than the Accord + Arsenal and Pathway treatments (Figure 2). There were no statistically significant differences in herbicide use among treatments in June and November.

The quantity of herbicide applied also differed among treatment dates but varied by herbicide mix (Figure 2). More herbicide was applied in June for the Accord + Arsenal than in April or November. The quantity of herbicide applied for the Garlon $4+$ Stalker treatment was greatest in Aprilnearly twice as much as any other treatment. There were no statistically significant differences in the amount of Pathway applied among dates.

There was no clear pattern between herbicide use and percentage mortality ( $r=0.19, P=0.34, n=27$ ). Percentage

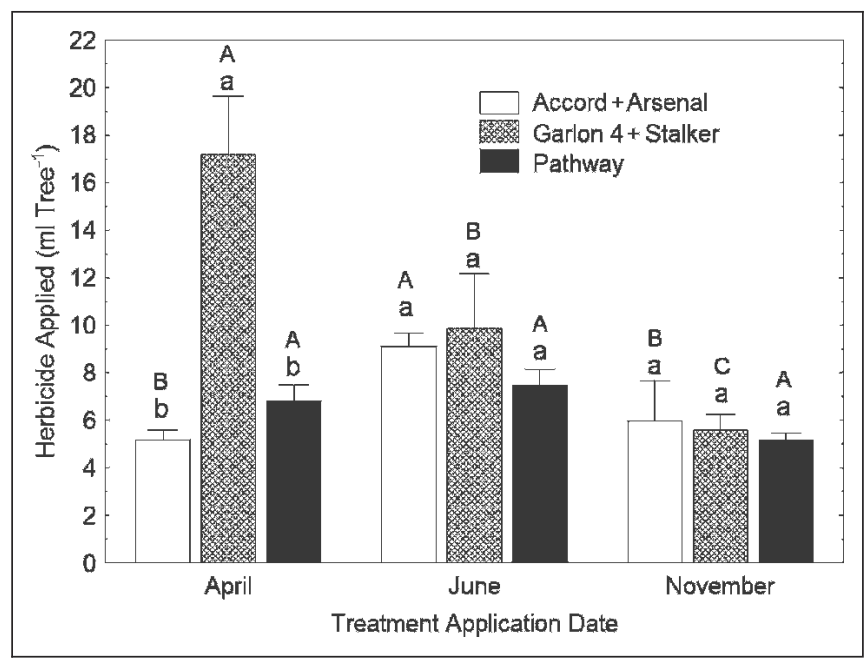

Figure 2. Quantity of herbicide applied per tree for three cut-stump herbicide treatments (Accord + Arsenal, GarIon 4 + Stalker, and Pathway) applied at three times of the year (19 April, 26-27 June, and 28 November 2000). Error bars represent one standard error of the mean. Bars with different lowercase letters denote significant differences $(\alpha=0.10$ ) among herbicide mixes for a given date; bars with different uppercase letters denote significant differences among dates for a given herbicide mix. 
mortality was high for all treatment plots, indicating that enough herbicide was applied and that the amount of herbicide applied did not affect the mortality rate.

\section{DISCUSSION}

Results from this study demonstrate a wide treatment window for cut-stump treatment of common hardwood trees on rightsof-way from April to November. Maximizing the percentage mortality throughout this range of treatment dates may be contingent upon matching herbicide mix to the date of application. With over $90 \%$ mortality, Garlon $4+$ Stalker or Pathway could be used from April through November, but the Accord + Arsenal mix should be used only in the fall.

\section{Comparison with Other Studies}

Studies of cut-stump treatments to control hardwood trees were rather limited, but in those that have been published, the efficacy of treatments was generally lower than we observed. For example, the percentage mortality 2 years after cut-stump treatment with glyphosate, 2,4-D + picloram, and triclopyr ranged from $46 \%$ to $66 \%$ for applications made during the dormant season and $49 \%$ to $56 \%$ for growing-season applications, relative to an untreated control (Zedaker et al. 1987). Percentage mortality after one growing season for February cut-stump applications of picloram + 2,4-D, 2,4-DP + 2,4-D, and triclopyr ranged from 53\% to $94 \%$ in a study conducted in Arkansas, U.S. (Troth et al. 1986).

The high percentage mortality that we observed may be partially attributed to the relatively young, small trees treated and the immediate application of herbicide-applications were made to the cut surface within minutes after felling. In other studies, herbicide applications were made within 30 to 90 min (Troth et al. 1986) after cutting, or applied immediately after cutting to up to $4 \mathrm{hr}$ later (Zedaker et al. 1987). The delayed applications may account for some of the differences in tree mortality. In addition, we used mixtures that were not used in the other studies (triclopyr + imazapyr and glyphosate + imazapyr). Broader spectrum of control with herbicide mixtures may also account for high mortality. The use of tank mixtures has become more common in right-of-way vegetation management (Sulak and Kielbaso 2000). More effective, broad-spectrum mixtures may allow for reduced concentration of active ingredients in herbicide applications. Most of the herbicides used by Zedaker et al. (1987) and Troth et al. (1986) were undiluted, so active ingredient concentrations were more than double those used in our study. Despite using lower-concentration herbicide mixes in our study, percentage mortality was still very high. However, because the dose was not regulated in our study, concentration differences could be offset by higher application rates.

\section{Herbicide Mode of Action and Translocation}

Some of the observed differences among herbicide mixes and treatment dates may be related to the physiological processes occurring in hardwood trees during different seasons and translocation and mode of action of the herbicides. All of the herbicides used in the study can be translocated in the phloem. Glyphosate, triclopyr, and 2,4-D are translocated primarily symplastically (i.e., in the phloem), and imazapyr and picloram are readily transported in both the xylem and phloem (Ahrens 1994). Transport of sugars in the phloem is from "source" to "sink." For example, leaves serve as a source of photosynthate during the active growing season, so sugars are transported downward in the phloem from leaves to roots. Xylem flow is in the opposite direction. In the spring, the opposite occurs in the phloem: the roots are the source and developing leaves are the sink, so phloem transport is upward.

For herbicides to kill hardwood trees with the cut-stump treatment, they must move to growing points in the plant, such as roots, buds on the stump and root collar, or roots of suckering species. This has been demonstrated for root suckering American beech (Fagus grandifolia) using stem injection (Kochenderfer et al. 2004). By severing the stem, a source or sink, depending on the season, is removed. Immediate application of herbicide to cut stems of dogfennel ( $\mathrm{Eu}$ patorium capillifolium) demonstrated that xylem cavitation can initially pull herbicide inward, but after xylem flow halts due to the formation of air pockets, the herbicide likely diffuses laterally to sieve elements and is translocated via phloem to the roots (Wahlers et al. 1997). Because sap flow in the phloem in spring is primarily upward, it may be difficult for translocation of phloem-mobile herbicides toward the roots, particularly those with very low $\mathrm{K}_{\mathrm{ow}}$ (e.g., glyphosate; Table 1). In the fall, movement of sugars is downward in the phloem to the root storage tissues, so herbicide transport toward the roots is more likely.

All three herbicide mixtures used in this study included one herbicide that is translocated primarily in the phloem and one that is readily translocated in both xylem and phloem. Garlon $4+$ Stalker (triclopyr and imazapyr) and Pathway (2,4-D and picloram) worked well at all three dates of application. The poorest-performing mixture was Accord + Arsenal (glyphosate + imazapyr), except in the fall. In another study, latesummer treatments with glyphosate using the hack-and-squirt method were very effective at controlling beech root suckering (Abrahamson 1983). Glyphosate has been found to perform better in the fall compared to spring or summer in other perennial plants (e.g., Johnsongrass; Lourens and Bayer 1996), because sugar transport to the rhizomes was greater in the fall. In addition, the very low $\mathrm{K}_{\mathrm{ow}}$ values (Table 1) associated with glyphosate indicates that this herbicide has optimal permeability to enter and stay in the phloem (Grimm et al. 1995). Therefore, in the spring, when phloem transport is upward, glyphosate would be "pushed out" rather than pulled down to the roots from the cut surface. However, in the fall, 
glyphosate would be transported toward the roots. We can also speculate that in the dormant season, glyphosate would be less effective because it requires translocation to the roots and metabolic activity. February and March (dormant season) cut-stump applications of undiluted glyphosate as Roundup ${ }^{\circledR}$ had lower efficacy than June and July applications (Zedaker et al. 1987), supporting this supposition.

\section{Practical Implications}

Overall mortality for all herbicide mixtures was high, with all mixes having over a $90 \%$ mortality rate with at least one application date. This level of performance is considered effective for right-of-way vegetation management programs using highly selective, individual-stem treatments (K. Finch, pers. comm.). Conversely, vegetation managers should recognize that up to $\sim 10 \%$ of the treated trees may live after treatment, even when that treatment is properly applied and matched with application date. Practitioners should anticipate that some trees will survive, especially since all it takes is one tree in the wrong place to affect transmission system safety and reliability. As with any herbicide treatment, lack of uniform coverage would increase the percentage of trees surviving treatment.

On power line rights-of-way in the Northeast, treating undesirable hardwood trees in wetlands is made more difficult by the limited number of herbicides that are approved for use in these sensitive areas. Accord + Arsenal is an important herbicide mixture for use in wetlands (K. Finch, pers. comm.), and if given a choice for date of application, vegetation managers should make Accord + Arsenal applications in the fall to optimize efficacy.

Application technique and the amount of herbicide applied are important considerations for efficient use of materials, minimizing costs, and reducing potential nontarget effects of treatments. While the amount of herbicide used to treat the plots-12.6 L/ha (5.4 qt/ac) —was consistent with normal, operational use of cut-stump treatment in plots with over 1,600 treatable stems/ha (650 stems/ac) (K. Finch, pers. comm.), we observed that the amount of herbicide used varied by date and herbicide mix, but with no apparent reduction in percentage mortality. Patterns of percentage mortality and amount of herbicide used were not correlated. Herbicide may have been overapplied. One indication of overapplication was the quantity of herbicide applied for the Garlon $4+$ Stalker treatment in April, which was nearly twice as much as any other treatment in the study.

The pattern of variability we observed in the quantity of herbicide used suggests that herbicide use was strongly influenced by hand-pump spray bottle versus trigger spray bottle. Variability may also have been influenced by application technique via different individuals within and between crews. The November crew using the trigger spray bottle tended to use less volume of herbicide than the June crew using the hand-pump spray bottle. In a separate study of the cut-stump treatments in June, we reported that nearly half of the herbicide was applied off-target in a $0.6 \mathrm{~m}(2 \mathrm{ft})$ diameter circular zone around the cut stump (Nowak and Ballard 2005). This is an important point when considering the relatively high concentration of active ingredient in the cut-stump treatments, especially for those herbicides with higher soil activity such as picloram and imazapyr. With awareness and proper equipment, it may be possible to significantly reduce the amount of herbicide used in cut-stump treatment while maintaining a high mortality rate. Future research in this area is warranted, including the testing of application equipment.

In addition, because the study was intended to evaluate the operational application of these treatments, we did not control the dose of herbicide applied. We suspect that lower rates could be applied, especially for the Garlon $4+$ Stalker treatment in spring, and still achieve a high percentage mortality, but this warrants further study. Our results and suggestions should also be evaluated for other regions and site conditions with additional target tree species. The treatments should also be evaluated for different years because weather conditions could affect how well herbicides perform.

\section{CONCLUSIONS}

Critical to the long-term success of right-of-way vegetation management are the continued advancements in basic and applied knowledge that allow vegetation mangers to make informed decisions when prescribing treatments. With the results from this study, vegetation managers can now make more informed decisions when selecting herbicide mixtures for different seasons: Garlon $4+$ Stalker or Pathway from early spring to fall, or Accord + Arsenal in the fall. In addition, minor refinements in application techniques and equipment have the potential to reduce the amount of herbicide used without adversely affecting the efficacy of the treatment, and these warrant further consideration. A high percentage mortality with operational cut-stump treatments on power line rights-of-way can be achieved over a wide range of treatment dates, from early spring to late fall, by selecting an appropriate herbicide mixture.

Acknowledgments. We acknowledge the following people and organizations for collegial and monetary support for this study: Dr. Larry Abrahamson, State University of New York; Dr. Ed Neuhauser, Ken Finch (retired), and Craig Allen, Niagara Mohawk, a National Grid Company; and Tom Sullivan, National Grid; Kevin McLoughlin (retired), Lew Payne, and George Stranovsky, New York Power Authority; Dick Mider, New York State Electric and Gas; Mike Fleming, BASF; Mark Rice and Dave Berk, Dupont; and Bill Sherksnas, Dow AgroSciences. We thank the following people for their technical support: Anne Barlow, Dan Charlebois, Christine Chodoba, Christopher Deegan, Rafael Herrera, Carrie Lorenz, Jason Magoon, Katie Moller, Byung-Bae Park, Angela Tewksbury, Matthew Todd, and Heather (Whittier) Luczak. We thank Dr. Larry 
Smart for input and discussion of plant physiology and herbicide mode of action and Kimberly Bohn, Leonard Machut, Dr. Shepard Zedaker, and Dr. Ruth Yanai for their reviews of earlier drafts of this paper.

\section{LITERATURE CITED}

Abrahamson, L.P. 1983. Control of Beech Root and Stump Sprouts by Herbicide Injection of Parent Trees. Forestry Research Note RN-SOF-81-001. SUNY College of Environmental Science and Forestry, Syracuse, NY.

Abrahamson, L.P., C.A. Nowak, P.M. Charlton, and P.G. Snyder. 1995. Cost effectiveness of herbicide and nonherbicide vegetation management methods for electric utility rights-of-way in the Northeast: state-of-the art review, pp. 27-43. In Proceedings of the Fifth International Symposium on Environmental Concerns in Rights-ofWay Management, September 19-22, 1993, Montreal, Quebec, Canada. Doucet, G.J., Séguin, C., and Giguère, M., Eds. Hydro-Québec, Quebec, Canada.

Ahrens, W.H. 1994. Herbicide Handbook, 7th ed. Weed Science Society of America, Champaign, IL.

Gangstad, E.O. 1989. Woody Brush Control. CRC Press, Inc., Boca Raton, FL.

Grimm, E., A. Grube, S. Jahnke, and S. Neumann. 1995. Retention of xenobiotics along the phloem path. Planta 197:11-18.

Kochenderfer, J.D., J.N. Kochenderfer, D.A. Warner, and G.W. Miller. 2004. Preharvest manual herbicide treatments for controlling American beech in central West Virginia. Northern Journal of Applied Forestry 21:40-49.

Lourens, A.F., and D.E. Bayer. 1996. Seasonal differences in carbohydrate and glyphosate accumulation in the rhizomes of Johnsongrass (Sorghum halepense). Applied Plant Science 10:37-41.

McLoughlin, K.T. 1997. Application of Integrated Pest Management to electric utility rights-of-way vegetation management in New York State, pp. 118-126. In Proceedings of the Sixth International Symposium on Environmental Concerns in Rights-of-Way Management, February 24-26, 1997, New Orleans, LA. William, J.R., GoodrichMahoney, J.W., Wisniewski, J.R., and Wisniewski, J., Eds. Elsevier Science Inc., New York, NY.

- 2002. Integrated Vegetation Management: the exploration of a concept to application, pp. 29-45. In Proceedings of the Seventh International Symposium on Environmental Concerns in Rights-of-Way Management, September 9-13, 2001, Calgary, Alberta, Canada. Goodrich-Mahoney, J.W., Mutrie, D.F., and Guild, C.A., Eds. Elsevier, Kidlington, Oxford, U.K.

Nowak, C.A., L.P. Abrahamson, E.F. Neuhauser, et al. 1992. Cost-effective vegetation management on a recently cleared electric transmission line right-of-way. Weed Technology 6:828-837.

Nowak, C.A., L.P. Abrahamson, and D.J. Raynal. 1993. Pow- erline corridor vegetation management trends in New York State: has a post-herbicide era begun? Journal of Arboriculture 19:20-26.

Nowak, C.A., and B.D. Ballard. 2005. Off-target herbicide deposition associated with treating individual trees. Environmental Management 36:237-247.

SAS Institute. 2002. SAS Institute, Inc., SAS Campus Drive, Cary, NC.

Sulak, J.A., and J.J. Kielbaso. 2000. Vegetation management along transmission utility lines in the United States and Canada. Journal of Arboriculture 26:198-205.

Troth, J.L., R.F. Lowery, and F.G. Fallis. 1986. Herbicides as cut-stump treatments during precommercial thinning, pp. 297-304. Proceedings of the 39th Annual Meeting of the Southern Weed Science Society, January 20-22, 1986, Nashville, TN. Southern Weed Science Society, Champaign, IL.

U.S. EPA. 1998. National primary drinking water regulations, contaminant specific fact sheets, synthetic organic chemicals-technical version. Revised January 23, 1998. U.S. Environmental Protection Agency, Office of Ground Water and Drinking Water, Washington, DC.

Wahlers, R.L., J.D. Burton, E.P. Maness, and W.A. Skroch. 1997. Physiological characteristics of a stem cut and blade delivery method of application. Weed Science 45: 746-749.

Zedaker, S.M., J.B. Lewis, D.W. Smith, and R.E. Kreh. 1987. Impact of season of harvest and site quality on cut-stump treatment of Piedmont hardwoods. Southern Journal of Applied Forestry 11:46-49.

Benjamin D. Ballard (corresponding author)

Research Scientist

Faculty of Forest and Natural Resources Management

State University of New York College of Environmental

Science and Forestry

218 Marshall Hall, 1 Forestry Drive

Syracuse, NY 13210, U.S.

bballard@esf.edu

Christopher A. Nowak

Associate Professor

Faculty of Forest and Natural Resources Management

State University of New York College of Environmental

Science and Forestry

215 Marshall Hall, 1 Forestry Drive

Syracuse, NY 13210, U.S.

canowak@esf.edu

Résumé. L'abattage des arbres à grand déploiement au sein des emprises de lignes de transport d'électricité est nécessaire pour la sécurité et la continuité du service. La coupe au niveau de la souche 
avec application d'herbicide a été employée à différents moments de l'année pour contrôler la formation de rejets de souche chez les espèces ligneuses indésirables au sein des lignes de transport du Nord-Est des États-Unis, et ce avec des degrés de succès variés. Les applications lors de la saison de croissance ont généralement été reconnues comme la période la plus efficace; cependant, si un pourcentage élevé de destruction pouvait être obtenu par la sélection d'un mélange approprié d'herbicides en applications tôt au printemps et tard en automne, les gestionnaires de végétation pourraient avoir ainsi plus de flexibilité dans la prescription et la période d'application. Nous avons évalué le pourcentage de mortalité et la quantité d'herbicide appliquée en avril, juin et novembre au moyen d'une coupe à la souche avec application de trois mélanges d'herbicide - Accord ${ }^{\mathrm{TM}}$ plus Arsenal ${ }^{\mathrm{TM}}$, Garlon ${ }^{\mathrm{TM}}$ plus Stalker ${ }^{\mathrm{TM}}$, et Pathway ${ }^{\mathrm{TM}}$. Le pourcentage de mortalité après deux ans était de plus $90 \%$ avec au moins un des mélanges d'herbicides, et ce lors des trois périodes d'application. Le pourcentage de mortalité variait à la fois selon le mélange et la période d'application compatible avec le mode d'action de l'herbicide. En avril et juin, Accord avec Arsenal avait un pourcentage de mortalité plus faible que le Garlon 4 avec Stalker ou Pathway; mais en novembre, ce même mélange avait un pourcentage de mortalité légèrement plus important qu'avec les deux autres mélanges. Le mélange Garlon 4 avec Stalker ainsi que le Pathway avaient des taux de mortalités élevés et équivalents à toutes les périodes d'application. L'utilisation avec succès de la méthode de la coupe au niveau de la souche depuis le printemps jusqu'en automne pourrait être contingentée en fonction de l'harmonisation des mélanges d'herbicide par rapport aux périodes d'application. Nos résultats indiquent que le Garlon 4 avec Stalker ou encore le Pathway peuvent être utilisés d'avril jusqu'en novembre, mais que les applications de Accord avec Arsenal devraient être faites à la fin de l'été ou en automne. Ces recommandations devraient être évaluées au sein d'autres régions avec d'autres espèces cibles d'arbres. La quantité d'herbicide utilisée par les équipes opérationnelles variait selon les périodes d'application et les mélanges d'herbicide, et apparaissait être fortement influencée par le type d'équipement utilisé ainsi que l'opérateur qui procédait à l'application. Des raffinements mineurs dans les techniques d'application et les équipements employés pourraient potentiellement permettre de réduire la quantité d'herbicide utilisée sans pour autant affecter négativement l'efficacité du traitement; de plus, cela pourrait permettre d'obtenir des gains en regard d'autres considérations.

Zusammenfassung. Die Entfernung von großen Bäumen unterhalb von Hochspannungsleitung ist notwendig für die Sicherheit der Leitungen. Herbizidbehandlungen der Stubben wurden zu verschiedenen Jahreszeiten angewendet, um ein Wiederaustreiben und Wachsen der unerwünschten Laubbäume unter den Leitungen zu verhindern. Dies geschah mit unterschiedlichem Erfolg. Eine Applikation während der Wachstumsphase wurde als höchst wirksam erachtet. Dennoch erschien eine hohe erzielte Absterberate auch durch eine gezielte Herbizidauswahl mit einer Frühjahr- oder Herbstapplikation zu erreichen zu sein, welches den Vegetationsmanagern mehr Spielraum und Flexibilität bei der Anwendung und Zeitgestaltung lassen würde. Wir bewerteten den Prozentsatz der getöteten Triebe und die Herbizidaufwendung im April, Juni und September mit drei Herbizidmischungen. Die Sterberate nach 2
Jahren betrug über $90 \%$ für mindestens eine Mischung in allen 3 Anwendungszeiträumen. Die Sterberate variierte bei beiden Mischungen und Applikationszeiträumen in Abhängigkeit von dem Herbizid. In April und Juni zeigte Accord plus Arsenal eine geringe Sterberate als Garlon 4 plus Stalker oder Pathway, aber im November gab es hier eine etwas höhere Sterberate als bei den anderen beiden Mischungen. Die Mischung Garlon 4 und Stalker sowie Pathway hatten zu allen Zeiträumen ähnliche Sterberaten. Eine erfolgreiche Anwendung der Stubbenbehandlung ist wohl abhängig davon, das richtige Mittel zur rechten Zeit einzusetzen. Unsere Ergebnisse zeigen, dass Garlon 4 plus Stalker und Pathway von August bis November wirksam ist, während Accord plus Arsenal im Spätsommer oder Herbst angewendet werden sollten. Diese Empfehlungen sollten in anderen Regionen mit anderen Baumarten ausprobiert werden. Die Menge der verwendeten Herbizide variierte bei den Anwendungszeiten und Mischungen, darüber hinaus hatte die anwendende Person und die Ausrüstung einen großen Einfluss. Kleine Verbesserungen der Applikationstechnik und der Ausrüstung hatten das Potential, die Menge des Herbizids zu verringern ohne die Effektivität der Behandlung zu beeinflussen.

Resumen. La remoción de árboles de crecimiento en altura en derechos de vía de transmisión eléctrica es necesaria para la seguridad y transmisión efectiva de la electricidad. Los tratamientos herbicidas han sido usados en diferentes ocasiones del año para controlar el rebrote de árboles de madera dura indeseados en el noreste de los Estados Unidos, con grados diferentes de éxito. Las aplicaciones en la estación de crecimiento han sido típicamente vistas como más efectivas; sin embargo, un alto porcentaje de muerte puede también ser apropiado para una aplicación en primavera temprana y otoño tardío, los manejadores podrían ser más flexibles en la prescripción y programación de los tratamientos. Evaluamos el por ciento de muerte y la cantidad de herbicida aplicado en Abril, Junio y Noviembre usando tratamientos operativos en la corta de tocones con tres mezclas herbicidas-Accord $₫$ más Arsenal ${ }^{\circledR}$, Garlon $4{ }^{\circledR}$ más Stalker@, y Pathway ${ }^{\circledR}$. El por ciento de muertes después de 2 años fue arriba del $90 \%$ para al menos una mezcla herbicida en las tres fechas de aplicación. El por ciento de muerte varió tanto para la mezcla como la fecha de aplicación y fue consistente con el modo de acción del herbicida. En Abril y Junio, Accord más Arsenal tuvo más bajo porcentaje de muerte que Garlon 4 más Stalker o Pathway, pero en Noviembre, tuvo levemente mayor porcentaje que las otras dos mezclas. Garlon 4 más Stalker mix y Pathway tuvieron igualmente altos porcentajes de muerte para todas las fechas de tratamiento. La utilización exitosa del método de destoconado en primavera y a través del otoño puede ser contingente una vez que se apliquen los herbicidas. Los resultados indican que Garlon 4 más Stalker o Pathway pueden ser usados desde Abril hasta Noviembre, pero las aplicaciones con Accord más Arsenal deben hacerse en el verano tardío u otoño. Estas recomendaciones deben ser evaluadas en otras regiones y con otras especies adicionales de árboles. $\mathrm{La}$ cantidad de herbicida utilizado por las brigadas operativas varió entre fechas de aplicaciones y mezclas herbicidas y estuvo fuertemente influenciada por el equipo de aspersión y la persona que aplicó el herbicida. Mejores refinamiento en las técnicas de aplicación y en el equipo tienen el potencial de reducir la cantidad de herbicida usado sin afectar adversamente la eficacia del tratamiento y la garantía de las anteriores consideraciones. 